\title{
The Relationship of Knowledge Pregnant Women about Fe Tablets and the Incidence of Anemia at Puskesmas Paraman Ampalu
}

\author{
Timmy Larasati, Maya Fernanda Dielsa
}

\begin{abstract}
Background: Pregnant anemia is called "Potential danger of mother and child".Their knowledge about anemia was very important to taking fe tablets. Methods: The design of this study was analytic descriptive. The data collection method in this research is in-dept-interview. Researchers obtained data by way of question and answer face to face withrespondents use the guidelinesinterview (questionnaire). Results: more than half of $67(53.6 \%)$ respondents have a high level of knowledge about Fe tablets and most of the $101(\mathbf{8 0 . 8 \%})$ respondents did not experience anemia. Conclusion: There was a significant relationship between the knowledge of pregnant women about Fe tablets and the incidence of anemia.
\end{abstract}

Index Terms - Knowledge, Anemia, Pregnant

\section{INTRODUCTION}

Anemia in pregnancy is a common problem because it reflects the value of the socio-economic welfare of the community and has a very large effect on the quality of human resources. Pregnant anemia is called "Potential danger of mother and child" (potential danger of mother and child), that's why anemia requires serious attention from all parties involved in health services on the next day.(1)

According to $\mathrm{WHO}$, the incidence of anemia in pregnancy ranges $(20 \%-89 \%)$ by determining $\mathrm{Hb}<11 \%$ of the base and $(35 \%-75 \%)$ is an anemia of $\mathrm{Fe}$ tablets deficiency which will increase with pregnancy. Meanwhile, maternal mortality in developing countries associated with the incidence of anemia in pregnancy is $40 \%$.(2)

The monthly report of the LB3 KIA book of the health office of the West Pasaman district in 2019, it was found that 398 pregnant women who were examined for $\mathrm{Hb}$ had anemia from 7801 pregnant women. Anemia is one of the indirect causes of maternal death.(3)

At PuskesmasParamanAmpalu, pregnant women are always given Fe tablets every ANC, but most of them do not know the importance of consuming $\mathrm{Fe}$ tablets so that pregnant women are not compliant to take Fe tablets. This phenomenon shows that the lack of knowledge of pregnant women about $\mathrm{HB}$ examination when pregnant, they come to the health center only to control the womb but do not ask the officers about HB testing for pregnant women.(4)

Providing information about anemia will increase. Their

Timmy Larasati,Midwifery Academy Pasaman Barat, West Sumatera Province, Indonesia

Maya Fernanda Dielsa, Midwifery Academy Pasaman Barat, West Sumatera Province, Indonesia knowledge about anemia, because knowledge plays a very important role so that pregnant women are obedient to taking Fe tablets.(5)

\section{MATERIALS AND METHODS}

\section{A. Study Design and ResearchSample}

The design of this study was analytic descriptive. The study was conducted at PuskesmasParamanAmpalu, West Pasaman, West Sumatera Province, Indonesia.Samplesize125people. Data were collected using a questionnaire with a validity value of 0.72 .

\section{B. OperationalDefinitions}

The variables of this study included independent variable is knowledge pregnant and dependent variable is incidence of anemia.

\section{Data CollectionTechnique}

The data collection method in this research is in-dept-interview. Researchers obtained data by way of question and answer face to face withrespondents use the guidelinesinterview (questionnaire).

\section{D.Data Analysis}

Data were analyzed univariately and bivariately. Univariate analysis in the form of distribution, data frequency, percentage and mean. Bivariate analysis using the ci square formula with $\mathrm{p}$ value $<0.05$.

\section{RESULTS}

Description of knowledge of pregnant women

Table 1: Frequency Distribution of knowledge of pregnant womenin the PuskesmasParamanAmpalu

\begin{tabular}{clll}
\hline No & Knowledge & f & \% \\
\hline 1 & High & 67 & 53.6 \\
2 & Low & 58 & 46.4 \\
\hline & Total & $\mathbf{1 2 5}$ & $\mathbf{1 0 0}$ \\
\hline
\end{tabular}

Table 1 showed that more than half of $67(53.6 \%)$ respondents have a high level of knowledge about Fe tablets. Descriptive of Anemia in Pregnant Women in the PuskesmasParamanAmpalu

Table 2: Frequency Distribution of Anemia in Pregnant Womenin the PuskesmasParamanAmpalu

\begin{tabular}{clll}
\hline No & Anemia & f & \% \\
\hline 1 & Anemia & 24 & 19.2 \\
2 & Not Anemia & 101 & 80.08 \\
\hline & Total & $\mathbf{1 2 5}$ & $\mathbf{1 0 0}$ \\
\hline
\end{tabular}

Table 2 showed that of the 125 respondents studied, most of 
the $101(80.8 \%)$ respondents did not experience anemia.

\section{DISCUSSION}

The result showedwhere the $p$ value $0.015(\leq 0.05)$ means thatthere is a significant relationship between knowledge and the incidence of anemia in PuskesmasParamanAmpalu.

According to the researchers, inadequate nutritional status is often associated with iron deficiency anemia. In ordinary gestations with one fetus, the mother's need for iron triggered by her pregnancy averaged close to $800 \mathrm{mg}$; about $500 \mathrm{mg}$, if available, for expansion of the maternal hemoglobin mass of about $200 \mathrm{mg}$ or more excreted through the intestines, urine and skin. This total amount of $1000 \mathrm{mg}$ clearly exceeds the iron stores of most women.Good knowledge of nutrition can increase the intake of Fetablets thereby reducing the prevalence of anemia in women.(6)

\section{CONCLUSION}

The conclusion of this study confirmed there was a significant relationship between knowledge and the incidence of anemia.

\section{ACKNOWLEDGMENT}

We would like to thank all respondents who participated in this study.

\section{REFERENCES}

[1] Yati Nurhayati. HUBUNGAN PENGETAHUAN IBU HAMIL TENTANG ANEMIA, STATUS GIZI IBU HAMIL DENGAN KEJADIAN ANEMIA DI DESA KENANGA KECAMATAN SINDANG KABUPATEN INDRAMAYU. J Kesehat Indra Husada [Internet]. 2018;6(1):39. Available from: https://doi.org/10.36973/jkih.v6i1.63

[2] World Health Organization. Part II: Global health indicators. World Heal Stat 2015. 2015;39-160.

[3] Provinsi Sumbar D. Jln. Perintis Kemerdekaan No.65A Padang. 2018;(65).

[4] Dinas Kesehatan Kabupaten Pasaman Barat. Report KIA. Simpang Empat; 2019.

[5] Febrianti R. Hubungan Konsumsi Tablet Fe Dengan Kejadian Anemia Pada Ibu Hamil Di Puskesmas Ambacang Kota Padang Tahun 2016. Menara Ilmu [Internet]. 2017;XI(76):106-14. Available from: file:///C:/Users/ASUS/AppData/Local/Packages/Microsoft.MicrosoftE dge 8 wekyb3d8bbwe/TempState/Downloads/287-525-1-SM (2).pdf

[6] Seu MMV, Mose JC, Panigoro R, Sahiratmadja E. Anemia Prevalence after Iron Supplementation among Pregnant Women in Midwifes Practice of Primary Health Care Facilities in Eastern Indonesia. Anemia. 2019;2019. 